\title{
Rotavirus gastroenteritis in a children's hospital specialized in craniofacial malformations
}

Vieira NA (1), Pereira PCM (2), Carvalho LR (3)

(1) Hospital for Rehabilitation of Craniofacial Anomalies, University of São Paulo, USP, Bauru, São Paulo State, Brazil; (2) Department of Tropical Diseases, Botucatu Medical School, São Paulo State University (UNESP - Univ Estadual Paulista), Botucatu, São Paulo State, Brazil; (3) Botucatu Biosciences Institute, São Paulo State University (UNESP - Univ Estadual Paulista), Botucatu, São Paulo State, Brazil.

\begin{abstract}
This study aimed to verify the relationship between acute diarrhea provoked by rotavirus and different indicators of craniofacial malformations. In the Hospital for Rehabilitation of Craniofacial Anomalies, 8,724 children with cleft lip and cleft palate were divided into the following groups: acute diarrhea and infection due to rotavirus $(C 1, n=62)$, acute diarrhea $(C 2, n=153)$ and without acute diarrhea $(C 3, n$ $=8,509$ ). In C1, 29.03\% of the cases consisted of hospital infections associated with the hospitalization period while $38.71 \%$ of the patients were aged less than six months. The percentage of children not having breastfed was significantly higher in acute diarrhea groups. Additionally, there was a seasonal prevalence of rotavirus infection between May and October. Finally, the present findings indicate that rotavirus is a predominant etiological agent for gastroenteritis in children with craniofacial malformations. Moreover, among infants younger than six months of age, type of craniofacial malformation, breastfeeding difficulty, socioeconomic level and longer hospitalization period appear to contribute to higher infection morbidity.
\end{abstract}

KEY WORDS: rotavirus, gastroenteritis, diarrhea, child.

CONFLICTS OF INTEREST: There is no conflict.

\section{CORRESPONDENCE TO:}

NARCISO ALMEIDA VIEIRA, Hospital de Reabilitação de Anomalias Craniofaciais, USP, Rua Silvio Marchione, 3-20, Vila Universitária, Bauru, SP, 17012-900, Brasil. Phone: +55 14 32358100. Fax: +55 14 32347818. Email: vieirana@usp.br. 
Vieira NA et al. Rotavirus gastroenteritis in a children's hospital specialized in craniofacial malformations. J Venom Anim Toxins incl Trop Dis. 2010;16(2):356

\section{INTRODUCTION}

Diarrhea is one of the most common causes of infant morbidity and mortality in developing countries. It is estimated that five million children under five years of age die every year throughout the world (1-3). In infants less than one year old, viruses cause $45 \%$ of the diarrhea cases while in children under four years, they are responsible for $40 \%$ of cases. Rotavirus provokes about 125 million acute diarrhea episodes per year, particularly in tropical regions, of which approximately one million are fatal (4). Even in developed countries, where satisfactory sanitation and hygiene conditions prevail, these agents are associated with epidemic occurrences including some deaths $(5,6)$.

Rotaviruses are transmitted through the oral-fecal route, and after a one to three-day incubation period they cause fever, vomiting and diarrhea, which can last up to ten days (7). This virus is highly contagious and transmitted rapidly among children that comprise the most at-risk group. It is also the most frequent enteropathogen that provokes nosocomial infectious diarrhea $(2,8)$. Hospital- or community-acquired rotavirus infections have been poorly addressed in national epidemiological studies (9). The existence of this specialized craniofacial hospital that treats children from the whole country and where infectious diarrhea has been observed for years reinforced the importance of better ascertaining infections caused by rotavirus in children with craniofacial malformations and led to the accomplishment of the present study.

Craniofacial anomalies - including cleft lip with or without cleft palate, isolated cleft palate, Robin sequence (RS) and others - result from alterations during embryonic development and can be detected in embryos aged only a few days (10). The RS, in general, is defined as a triad of craniofacial anomalies, characterized by micrognathia and glossoptosis, with or without cleft palate (11).

Cleft palate compromises the negative intraoral pressure during sucking, causing insufficient ingestion of milk and frequently impairing breastfeeding (12). This situation may lead to compromised nutritional evolution, thus exposing the child to infections. The factors of nutrition, infection and immunity - as well as probable cultural and socioeconomic conditions - contribute to this malady.

Cleft palate also causes an opening between the oral and nasal cavities, which is even more detrimental to feeding, given the loss of food through the nose or by aspiration, which causes respiratory infections and recurrent otitis. 
By studying children with cleft lip and/or cleft palate from birth to 2.5 years of age, it was observed that respiratory infections were frequent during the first three months and had a negative influence on the growth process, as measured by weight and height. Even though cranial circumferences were normal, feeding difficulties and intestinal problems prevailed from 12 to 18 months of age (13).

The nutritional condition plays an important role in the host susceptibility to bacterial, parasitic and viral infections. However, the infection itself precipitates the signs and symptoms of nutritional deficiency in malnourished children and, then, these symptoms can worsen the evolution of the infectious processes. Malnutrition and infection interact synergistically and constitute a public health concern, especially in places with poor sanitation, where poverty and ignorance influence feeding habits.

Little is known about the repercussion that clefts can have on the nutritional condition of patients. Infants with clefts may have their nutrition compromised due to feeding problems that result from impaired sucking, immediately after birth, caused by the oral conditions inherent to the cleft, which leads to varying degrees of malnutrition (14).

This study aimed at verifying and characterizing the occurrence of acute rotavirus diarrhea in children assisted at the Hospital for Rehabilitation of Craniofacial Anomalies of the University of São Paulo (HRAC/USP) from January to December 2002, using laboratory, clinical, socioeconomic and cultural indicators.

\section{MATERIALS AND METHODS}

A total of 8,724 patients of both genders, aged up to five years, were retrospectively studied. They had been treated at the Outpatient Clinic (OC), Nursery Ward (NW), Special Care Unit (SCU) or Intensive Care Unit (ICU) of HRAC/USP between January and December 2002. This study employed data from the clinical records of children who received specific treatment at the institution, whether or not they were diagnosed with acute diarrhea.

Three groups were formed: C1, 62 children with confirmed diagnosis of acute diarrhea caused by rotavirus; C2, 153 children with acute diarrhea but negative for rotavirus; and $\mathrm{C} 3,8,509$ children with no diagnosis of acute diarrhea, thus characterizing the control group. 
Patients were classified according to the type of craniofacial malformation, as follows: cleft lip with or without cleft palate, isolated cleft palate, Robin sequence and other malformations.

Acute diarrhea was characterized by the occurrence of more than three evacuations per day and/or alteration in bowel habits (increase in fecal volume and/or fluid feces with or without increase in the evacuation frequency). According to the Hospital Infection Control Committee of HRCA/USP, which indicates urgent assessment of rotavirus in feces in cases of acute diarrhea, all examinations were carried out immediately after feces collection at the Clinical Pathology Laboratory at HRAC/USP. The presence of acute diarrhea due to rotavirus in children was classified into community or hospital infection according to the hospitalization period. It was considered a hospital infection when the child had been hospitalized for more than three days in one of the HRAC/USP units.

Children with acute diarrhea (C1 and C2) were evaluated for weight and age using the National Center for Health Statistics (NCHS) (15) reference curve for achievement of the respective percentiles, in which the normality threshold is superior to the tenth percentile.

Socioeconomic classification took into account the following parameters: family's economic situation, number of family members, schooling, housing type and occupation. This categorization utilized a simple point system that was then classified into: low inferior, low superior, medium inferior, medium, medium superior and high groups according to Graciano's socioeconomic classification (16).

All patients with acute diarrhea were investigated for the presence of rotavirus in feces and subjected to hematological tests. Analyzes were carried out at the Clinical Pathology Laboratory at HRAC/USP.

Feces samples were collected after natural evacuation and immediately sent, in appropriate metal or plastic containers, to the laboratory. Determination of rotavirus presence (antigen VP6) in fecal samples was performed by immunochromatographic analysis, using specific monoclonal antibodies against antigen VP6 of group A human rotavirus.

Frequency tables were arranged based on the clinical history information of each patient. The chi-square test was employed for comparisons among groups and respective percentiles, the Tukey's test for comparison of proportions, the Kruskal- 
Wallis test for comparison of hospitalization period, and the Student-Newman-Keuls test for comparison of hospital units in each group. The significance level of $p<0.05$ was adopted for all tests (17).

The study was revised and approved by the Research Ethics Committee of HRACUSP (n. 79/2008, SVAPEPE-CEP).

\section{RESULTS}

There was no statistically significant difference in gender distribution in groups C1, $\mathrm{C} 2$, and C3; $56.67 \%$ of the children were male. White children were predominant in all groups, namely $87.10 \%$ in C1, $90.20 \%$ in C2, and $71.32 \%$ in C3.

Table 1 shows that $24(38.71 \%)$ infants with acute rotavirus diarrhea aged six months or less and only three (4.84\%) children aged more than 36 months, whereas 68 (44.44\%) children with acute diarrhea aged six months or less and 19 (12.42\%) were older than 36 months. Both groups differed from the control group.

Table 1. Age distribution of 8,724 children with craniofacial malformations

\begin{tabular}{l|c|c|c|c}
\hline \multicolumn{1}{|c|}{ Patients } & $\begin{array}{c}\text { C1 } \\
\mathbf{n ( \% )}\end{array}$ & $\begin{array}{c}\text { C2 } \\
\mathbf{n}(\%)\end{array}$ & $\begin{array}{c}\text { C3 } \\
\mathbf{n}(\%)\end{array}$ & $\begin{array}{c}\text { Total } \\
\mathbf{n}(\%)\end{array}$ \\
\hline Up to 6 & $24(38.71)$ & $68(44.44)$ & $138(1.62)$ & $230(2.64)$ \\
\hline 7 to 12 & $20(32.26)$ & $31(20.26)$ & $567(6.66)$ & $618(7.08)$ \\
\hline 13 to 36 & $15(24.19)$ & $35(22.88)$ & $3354(39.42)$ & $3404(39.02)$ \\
\hline Over 36 & $3(4.84)$ & $19(12.42)$ & $4450(52.30)$ & $4472(51.26)$ \\
\hline Total & $\mathbf{6 2 ( 1 0 0 . 0 0 )}$ & $\mathbf{1 5 3 ( \mathbf { 1 0 0 . 0 0 ) }}$ & $\mathbf{8 5 0 9 ( \mathbf { 1 0 0 . 0 0 ) }}$ & $\mathbf{8 7 2 4 ( \mathbf { 1 0 0 } . 0 0 )}$ \\
\hline
\end{tabular}

C1: children with diarrhea and infection due to rotavirus

C2: children with diarrhea

C3: children without diarrhea or infection due to rotavirus

\begin{tabular}{c|c|c|c}
\hline Hypothesis & $\begin{array}{c}\text { Calculated } \\
\text { statistics }\end{array}$ & Significance level & Comments \\
\hline $\mathrm{n} 1=\mathrm{n} 2=\mathrm{n} 3=\mathrm{n} 4$ & $\mathrm{X}^{2}{ }_{4}=1535.6$ & $\mathrm{p}=0.000$ & $\begin{array}{c}\text { At least one of the } \\
\text { proportions differs }\end{array}$ \\
\hline
\end{tabular}

The majority of the studied children were from São Paulo state. In C1, 27 (43.54\%) children came from the Federal District and states of Espírito Santo, Mato Grosso do 
Sul, Minas Gerais and Paraná; C2 had 49 (32.03\%) components from the states of Minas Gerais, Mato Grosso do Sul and Paraná.

The low inferior and low superior socioeconomic levels prevailed in all groups: C1 with 57 (91.94\%) children, C2 with 132 (86.27\%), and C3 with 2,406 (75.55\%). Regarding the formal education level of the caretakers, 40 (64.51\%) in C1, 89 (58.13\%) in C2 and 3,455 (40.61\%) in C3 had not completed elementary and middle school.

Figure 1 shows the distribution of acute diarrhea cases (groups C1 and C2) by months, demonstrating higher number of rotavirus cases between May and October.

- C1 - Diarrhea from rotavirus

m C2 - Diarrhea

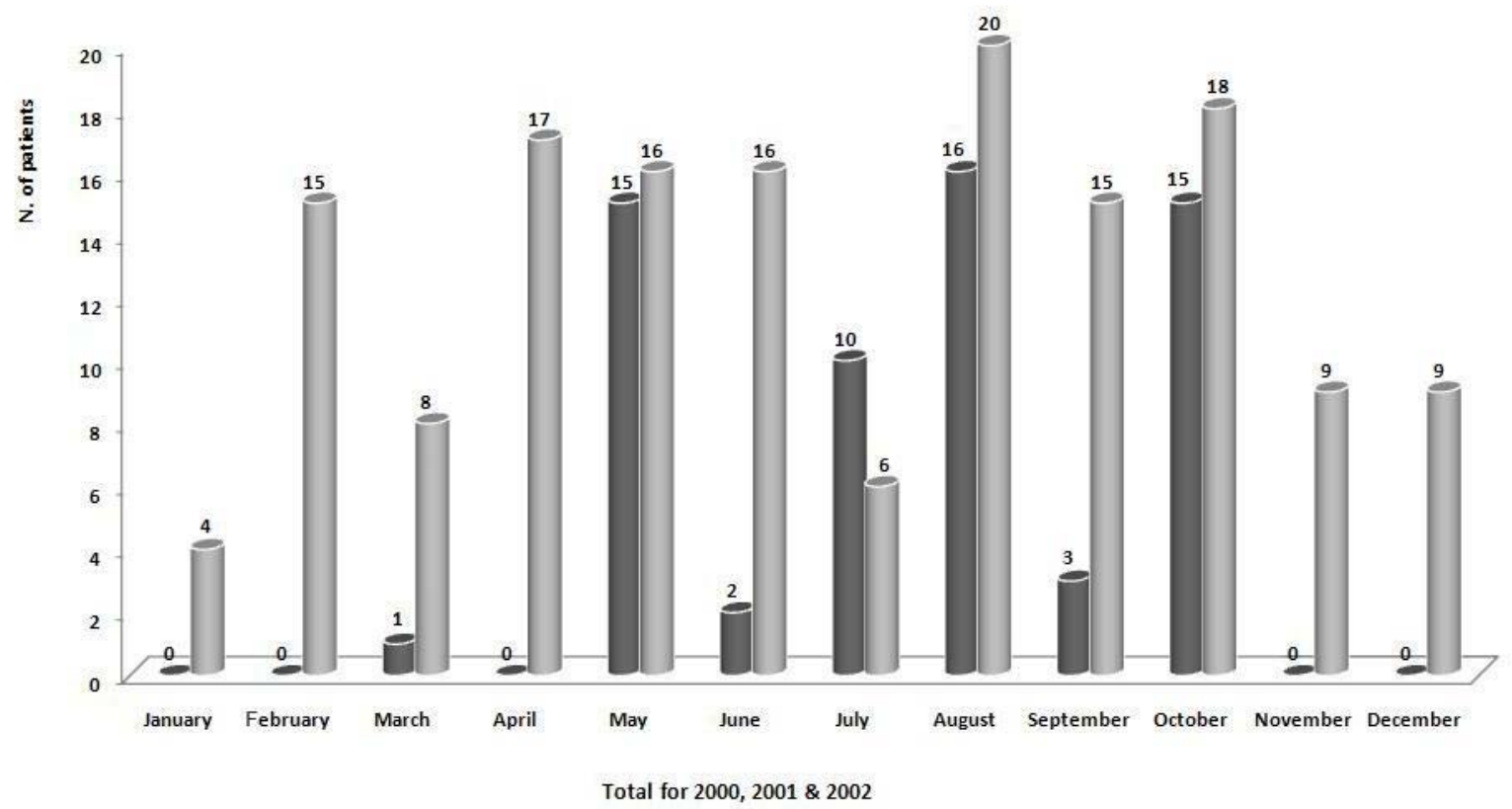

Figure 1. Distribution of 215 children with craniofacial malformations and diarrhea of groups C1 and C2 according to months, from 2000 to 2002.

Table 2 shows that of the 215 children with acute diarrhea (groups C1 and C2), 112 (52.10\%) were from the outpatient clinic. As for hospital infection, $13(72.22 \%)$ C1 children were from the SCU with an average hospital stay of 36.5 days.

Table 3 displays that the number of children with cleft lip prevailed in all groups and the number of children with Pierre Robin sequence was proportionally higher in groups C1 and C2 than in C3. 
Table 2. Distribution of 215 children with craniofacial malformations of groups $\mathrm{C} 1$ and C2 by hospital unit

\begin{tabular}{|c|c|c|c|}
\hline Hospital Unit & $\begin{array}{c}\text { C1 } \\
\text { n (\%) }\end{array}$ & $\begin{array}{c}\text { C2 } \\
\mathrm{n}(\%)\end{array}$ & $\begin{array}{l}\text { Total } \\
\text { n (\%) }\end{array}$ \\
\hline Outpatient Clinic (OC) & $29(46.77)$ & $83(54.25)$ & $112(52.10)$ \\
\hline Nursery Ward (NW) & $15(24.20)$ & $23(15.03)$ & $38(17.67)$ \\
\hline Special Care Unit (SCU) & $14(22.58)$ & $33(21.57)$ & $47(21.86)$ \\
\hline Intensive Care Unit (ICU) & $4(6.45)$ & $14(9.15)$ & $18(8.37)$ \\
\hline Overall total & $62(100.00)$ & $153(100.00)$ & $215(100.00)$ \\
\hline
\end{tabular}

C1: children with diarrhea and infection due to rotavirus

C2: children with diarrhea

\begin{tabular}{c|c|c|c}
\hline Hypothesis & $\begin{array}{c}\text { Calculated } \\
\text { statistics }\end{array}$ & $\begin{array}{c}\text { Level of } \\
\text { significance }\end{array}$ & Comments \\
\hline $\mathrm{OC}=\mathrm{IN}=\mathrm{SCU}=\mathrm{ICU}$ & $\mathrm{X}^{2}{ }_{4}=2.9$ & $\mathrm{p}=0.4$ & $\mathrm{OC}=\mathrm{IN}=\mathrm{SCU}=\mathrm{ICU}$ \\
\hline
\end{tabular}

Table 3. Distribution of the 8,724 children with craniofacial malformations of groups C1, C2 and C3 according to the type of craniofacial malformation

\begin{tabular}{l|c|c|c|c}
\hline \multicolumn{1}{|c|}{ Patients } & $\begin{array}{c}\text { C1 } \\
\mathbf{n}(\%)\end{array}$ & $\begin{array}{c}\text { C2 } \\
\mathbf{n ( \% )}\end{array}$ & $\begin{array}{c}\text { C3 } \\
\mathbf{n}(\%)\end{array}$ & $\begin{array}{c}\text { Total } \\
\mathbf{n}(\%)\end{array}$ \\
\hline $\begin{array}{l}\text { Type of malformation } \\
(\mathrm{n}=1)\end{array}$ & $39(62.90)$ & $101(66.01)$ & $5381(63.24)$ & $5521(63.29)$ \\
\hline Cleft palate $(\mathrm{n}=2)$ & $2(3.23)$ & $18(11.76)$ & $1668(19.60)$ & $1688(19.35)$ \\
\hline Pierre Robin sequence $(\mathrm{n}=3)$ & $10(16.13)$ & $16(10.46)$ & $275(3.23)$ & $301(3.45)$ \\
\hline Other malformations $(\mathrm{n}=4)$ & $11(17.74)$ & $18(11.77)$ & $637(7.49)$ & $666(7.63)$ \\
\hline No information $(\mathrm{n}=5)$ & $0(0.00)$ & $0(0.00)$ & $548(6.44)$ & $548(6.28)$ \\
\hline Total & $\mathbf{6 2 ( \mathbf { 1 0 0 . 0 0 ) }}$ & $\mathbf{1 5 3 ( \mathbf { 1 0 0 . 0 0 ) }}$ & $\begin{array}{c}\mathbf{8 5 0 9} \\
\mathbf{( 1 0 0 . 0 0 )}\end{array}$ & $\begin{array}{c}\mathbf{8 7 2 4} \\
\mathbf{( 1 0 0 . 0 0 )}\end{array}$ \\
\hline
\end{tabular}

C1: children with diarrhea and infection due to rotavirus

C2: children with diarrhea

C3: children without diarrhea

Figure 2 shows that of the 215 children with acute diarrhea (C1 and C2), 64.29\% were from $\mathrm{C} 1$ and $90.9 \%$ were from C2, they all presented low weight-for-age index (below 10 percentile) and were from special care units. 
Data from mothers who informed about breastfeeding showed that $42.86 \%$ of the children with diarrhea (groups C1 and C2) had not been breastfed and had not been fed with human milk.

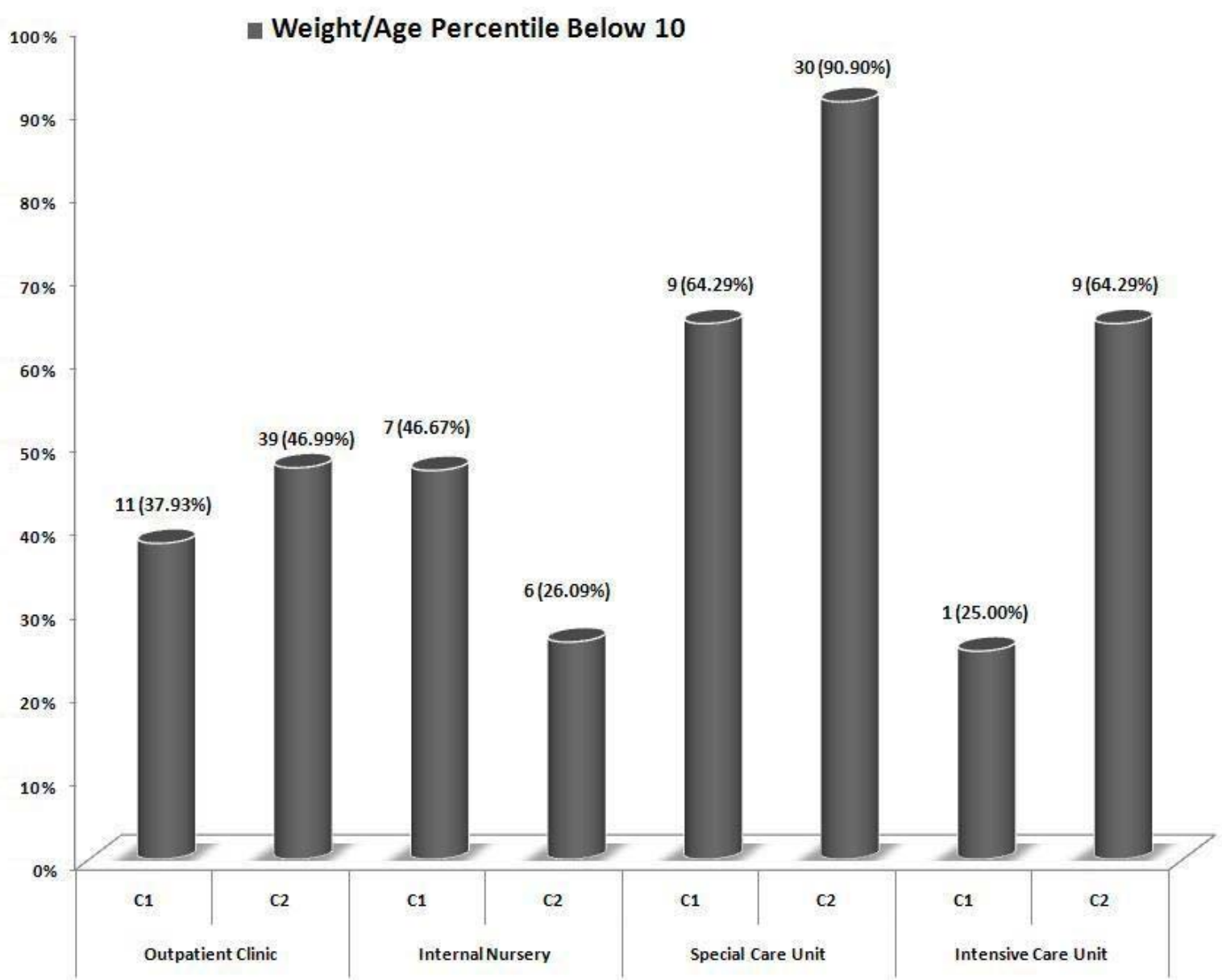

Figure 2. Percentage of children with craniofacial malformations in groups $C 1$ and $C 2$ with weight-for-age percentile below 10 by NCHS, according to the hospital unit.

\section{DISCUSSION}

Rotavirus infections acquired in hospitals or in the community are still poorly addressed in national epidemiological studies, especially in children with craniofacial malformations (9). The presence of cleft palate, which impairs sucking, may expose children to different infections, including acute diarrhea. Similar results to those of the present study were found in previous works on children without this anomaly, in which about $30 \%$ of the cases of infant acute diarrhea were provoked by rotavirus. It is important to highlight that there are no studies on this pathology in children with craniofacial malformation. 
Concerning ethnic diversity, data showed a higher prevalence of white children in all studied groups. Comparing this parameter with population distribution by skin color in Brazil, according to the Brazilian Institute of Geography and Statistics (IBGE), white individuals prevail, followed by mulatto, black and yellow persons (18). In a study published in 1974, it was demonstrated that these differences influence statistics of cleft lip and palate, namely affecting 1:700 births in white people and 2:1,000 in black people. These data show that black people are more resistant than white people (19). Therefore, the present results agree with the literature (20).

Rotavirus plays an important role in a hospital environment, since this virus is physically-chemically resistant presents high transmissibility (21). Studies on volunteers reveal that the fecal-oral route is the basic mechanism for interhuman propagation of rotavirus. It is estimated that these virulent agents are eliminated in concentrations that reach a trillion particles per milliliter of fecal specimen during acute phases of diarrhea, and only 10 virions are needed to start the infectious process (20). In the city of Belém, these data were associated with about one third of hospital diarrhea cases in children without craniofacial malformations (22). The latter study showed that nearly half of the children with acute diarrhea had been seen at the outpatient clinic, and in about $25 \%$ of these cases the rotavirus was confirmed. Approximately one third of the children with acute diarrhea and infection due to rotavirus were considered hospital infection cases, mostly acquired in the Special Care Unit (SCU). The hospitalization period was associated with a higher risk of intrahospital infection.

Acute diarrhea predominated in children up to six months of age, regardless of the cause. These data differed from the analyses made in urban areas of Porto Velho, Rondônia state, which found higher incidences of rotavirus in children without craniofacial malformations between six and 24 months $(2,7)$. They also diverged from the study carried out in a children hospital of Nicaragua, which showed higher incidence of acute diarrhea in children without craniofacial malformations between seven and 12 months (23). Other studies have demonstrated that in exclusively breastfed children, the length of diarrhea episodes is shorter than in children receiving non-human milk (24). The protective role of human milk can be attributed to its immunological anti-infective properties or to epithelial growth cell factors that stimulate renewal of the intestinal mucosa (25). 
Most infections due to rotavirus occur between six and 24 months of age, because in this period children are no longer breastfed and do not receive maternal antibodies transferred naturally through lactation (7). Moreover, nutritional impairment of children with cleft lip and palate leads to different levels of malnutrition $(14,26)$. The present study showed that children with isolated cleft lip had less feeding difficulties and could be breastfed significantly more often than children with cleft palate, and also that natural lactation is important not only for nutrition but also as a source of prevention against both respiratory and gastrointestinal infections (26).

Another aspect was that about half of the children presenting acute diarrhea had a weight/age percentile below ten, and a consequent exposure to diarrhea - especially to rotavirus infections. These children presented several types of malformation, which would indicate such low percentile.

Low inferior and low superior socioeconomic conditions were predominant in children with or without diarrhea. Thus, low socioeconomic conditions and the degree of gastroenteritis morbidity revealed a possible association with the incidence of rotavirus infection, similar to data from studies performed in children without craniofacial malformations (8). The low schooling of those responsible for the children was also significant, and it should be emphasized that the presence of a cleft also contributed to a higher predisposition to infections.

Various authors have reported epidemics caused by rotavirus in cold drier months. In Brazil, seasonal profiles were observed typically the Central-West, Southeast and South regions; it was not reported in the North and Northeast regions of the country (27). On the other hand, in tropical areas, seasonality is not so remarkable as in temperate regions; studies carried in Belém do Pará did not find seasonal variations in infections due to rotavirus (28). In the current work, higher infections levels at HRAC/USP due to rotavirus occurred between May and October, showing a typical seasonal pattern with more cases in drier months.

Finally, considering the importance of infections due to rotavirus in children with craniofacial malformations, other variables - including age (six months or less), type of craniofacial malformation, difficult breastfeeding, socioeconomic level and hospitalization period - must have contributed to the higher infection morbidity. 
Vieira NA et al. Rotavirus gastroenteritis in a children's hospital specialized in craniofacial malformations. J Venom Anim Toxins incl Trop Dis. 2010;16(2):365

\section{REFERENCES}

1. Mentz LM, Gonzalez MBA, Silva L, Traesel L, Pereira SC. Terapia de reidratação oral. Rev Med Hosp São Vicente de Paulo. 2000;11(26):39-40.

2. Orlandi PP, Silva T, Magalhães GF, Alves F, de Almeida Cunha RPA, Durlacher $\mathrm{R}$, et al. Enteropathogens associated with diarrheal disease in infants of poor urban areas of Porto Velho, Rondônia: a preliminary study. Mem Inst Oswaldo Cruz. 2001;96(5):621-5.

3. Riverón Corteguera RL, Mena Viranda VR, González Fernández MA. Morbilidad y mortalidad por enfermedades infecciosas intestinales *001/009: Cuba, 1980/1999. Rev Cubana Pediatr. 2000;72(2):72-80.

4. Institute of Medicine. The prospects for immunizing against rotavirus. In: New vaccine developments: establishing priorities. Diseases of importance in developing countries. Washington: National Academy Press; 1986. p. 308-18.

5. Glass RI, Lew JF, Gangarosa RE, LeBaron CW, Ho MS. Estimates of morbidity and mortality rates for diarrheal diseases in American children. J Pediatr. 1991;118(4 Pt 2):27-33.

6. Ho MS, Glass RI, Pinsky PF, Anderson LJ. Rotavirus as a cause of diarrheal morbidity and mortality in the United States. J Infect Dis. 1988;158(5):1112-6.

7. Linhares AC, Gabbay YB, Mascarenhas JDP, Oliveira CS, Gusmão RHP. Gastroenterites por rotavírus. In: Veronesi R, Focaccia R. Tratado de infectologia. São Paulo: Atheneu; 2002. p. 277-88.

8. Maranhão HS. Diarréia aguda: aspectos clínico-epidemiológicos, evolução nutricional e isolamento de enteropatógenos em lactentes na cidade do Natal, nordeste do Brasil. Elect J Ped Gas Nut Liv Dis. 2001;5(5). Available from: http://www.e-gastroped.com.br/teses/td012001.pdf

9. Linhares AC. Epidemiologia das infecções por rotavírus no Brasil e os desafios para o seu controle. Cad Saúde Pública. 2000;16(3):629-46.

10. Lofiego JL. Embriologia. In: Lofiego JL. Fissura lábio-palatina: avaliação, diagnóstico e tratamento fonoaudiológico. Rio de Janeiro: Revinter; 1992. p. 2044.

11. Marques IL, Peres SP, Bettiol H, Barbieri MA, Andrea M, De Souza L. Growth of children with isolated Robin sequence treated by nasopharyngeal intubation: importance of a hypercaloric diet. Cleft Palate Craniofac J. 2004;41(1):53-8. 
12. Richard ME. Weight comparisons of infants with complete cleft lip and palate. Pediatr Nurs. 1994;20(2):191-6.

13. Felix-Schollaart B, Hoeksma JB, Prahl-Andersen B. Growth comparison between children with cleft lip and/or palate and controls. Cleft Palate Craniofac J. 1992;29(5):475-80.

14. Capelloza Filho L, Silva Filho OG. Fissuras lábio-palatais. In: Petrelli E. Ortodontia para fonoaudiologia. São Paulo: Lovise; 1994. p. 195-239.

15. Centers for Disease Control and Prevention. National Center for Health Statistics. CDC Growth Charts. Atlanta: Centers for Disease Control and Prevention [updated August 4, 2009; cited 2009 June]. Available from: http://www.cdc.gov/growthcharts.

16. Graciano MIG, Lehfeld NAS, Neves Filho A. Critérios de avaliação para classificação sócio-econômica: elementos de atualização. Serv Social Realid. 1999;8(1):109-28.

17. Curi PR. Metodologia e análise de pesquisa em ciências biológicas. 2nd ed. Botucatu: Tipomic; 1998.

18. Instituto Brasileiro de Geografia e Estatística (IBGE). Indicadores sociais mínimos [Internet]. Brasília: Instituto Brasileiro de Geografia e Estatística [cited 2002 Oct]. Available from:

http://www.ibge.gov.br/home/estatistica/populacao/condicaodevida/indicadoresmi nimos/notasindicadores.shtm.

19. Fogh-Andersen P. Epidemiology and etiology of clefts. Birth Defects Orig Artic Ser. 1971;7(7):50-3.

20. Souza-Freitas JA. Centro de pesquisa e reabilitação de lesões lábio-palatais. Bauru: Faculdade de Odontologia de Bauru, Universidade de São Paulo; 1974.

21. LeBaron CW, Furutan NP, Lew JF, Allen JR, Gouvea V, Moe C, et al. Viral agents of gastroenteritis. Public health importance and outbreak management. MMWR Recomm Rep. 1990;39(RR-5):1-24.

22. Linhares AC, Moura JM, Gabbay YB, Mendes PS, Mascarenhas JD, de Azevedo RC. Rotavirus serotypes and electrophoretypes among children attending three paediatric hospitals in Belém, Brazil. J Trop Pediatr. 1993;39(3):137-41. 
23. Ojeda Rueda JJ. Rotavirus en niños menores de cinco años com diarrea aguda: Hospital Infantil JJR: La Mascota Diciembre 1999 - Febrero 2000 [thesis]. Manágua: Facultad de Ciências Médicas, Universidad Nacional Autônoma de Nicarágua; 2000. 45 p.

24. López-Alarcón M, Villalpando S, Fajardo A. Breast-feeding lowers the frequency and duration of acute respiratory infection and diarrhea in infants under six months of age. J Nutr. 1997;127(3):436-43.

25. Carpenter G. Epidermal growth factor is a major growth-promoting agent in human milk. Science. 1980;210(4466):198-9.

26. Montagnoli LC, Barbieri MA, Bettiol H, Marques IL, de Souza L. Growth impairment of children with different types of lip and palate clefts in the first 2 years of life: a cross-sectional study. J Pediatr. 2005;81(6):461-5.

27. Pereira HG, Linhares AC, Candeias JA, Glass RI. National laboratory surveillance of viral agents of gastroenteritis in Brazil. Bull Pan Am Health Organ. 1993;27(3):224-33.

28. Linhares AC, Gabbay YB, Freitas RB, Rosa ES, Mascarenhas JD, Loureiro EC. Logitudinal study of rotavirus infections among children from Belém, Brazil. Epidemiol Infect. 1989;102(1):129-45. 